\title{
Sources of Stress among the Nursing Students of Private Universities of Pakistan
}

\author{
${ }^{1}$ Muhammad Afzal ${ }^{*},{ }^{2}$ Ali Waqas, ${ }^{3}$ Muhammad Hussain, ${ }^{4}$ Naveed Sehar \\ ${ }^{1}$ Assistant Professor, The University of Lahore, Pakistan \\ ${ }^{2}$ Visiting Lecturer, The University of Lahore, Pakistan \\ ${ }^{3}$ Lecturer, The University of Lahore, Pakistan \\ ${ }^{4}$ BSN student, The University of Lahore, Pakistan \\ Email: muhammad.afzal@lsn.uol.edu.pk
}

\begin{abstract}
The emotional situation or demand of the work from the student may create stress among the nursing students. Stress for the students at class room is very common and altered their mental and physical health. Similarly, the tiring nature of clinical practice also reduce the performance and ability to gain the knowledge of the nursing students. Thus, aim of the current study is to investigate the sources of stress among the nursing students. The study consists of a sample of122 nursing students of the private universities of Lahore. The study results reveals that students of nursing experiences stress through the following four sources i.e. academics, clinical rotation, personal problems and environment. Furthermore, nursing students of private universities experiences more stress from the academic sources of stress than the other three categories. The study provides the recommendations and implications in the future findings.
\end{abstract}

Keywords: Stress, academic sources, clinical sources, personal sources, environmental sources, nursing students.

\section{Introduction}

Stress refers to a dynamic interaction between the individual and the environment where demands, limitations and opportunities related to work may be perceived as threat to surpass the person's capacity and skills (Edward, et al., 2015). Stressors can be defined as the conditions or events that have the potential to affect health (Pulido, 2012). Stress is the person's reaction to any exceeding demand at workplace. In addition, stress also provides the means to show creativity, abilities and energies; though it can also cause fatigue and sickness, either physical or psychological (Edward, et al., 2015). However, nursing students also face stress due to the different sources and clinical rotation during studies. Thus, stress being the psychological factor also influences the student's academic performance (Findik, et al., 2015).

During university life where the passionate relationship between the student and environment is unpredictable, thus, stress observation and reaction has key importance. Although, every profession is effected by stress but the health professionals are more susceptible to stress especially the nursing professionals (Edwards, et al., 2010). Stress among students may arise from the stressors like academic sources, environmental sources and may be due to emotions or personal issues. These stressors might disturb the student's learning capability and academic performance (Hayes, et al.,2015). Thus, it enhances the need to focus on the factors which causes student's stress. Furthermore, the study describes stress as a link among person and their atmosphere that is considered as hazardous (Hayes, et al., 2015).

Nursing students are more prone to stress as they have pressure of clinical placements along with study, workload of assignments, fear of failure, inability to balance study and leisure time (Findik, et al., 2015). Likewise, nursing students face pressures during the clinical rotation like handling of advanced technology, variation between the standard operating procedures and real situations in the healthcare environment, on-cooperative 
South American Journal of Nursing

Volume 2, Issue 1, 2016

behavior of clinical staff, fear of making mistakes during patient care and humiliating behavior of physicians. Beside these stressors, there are various other sources of stress among nursing students like personal and environmental issues i.e. congested class room environment contributes a lot to create stress (Edward, et al., 2015). However, personal issues such as decline in personal health, financial problems, lack of sleep, high parental expectations, lack of confidence and decision making ability are major sources of stress among nursing students (Edward, et al., 2015).

The identification of sources of stress among nursing students will bring a positive change in student's performance as well as teacher's attitude towards students which is somehow hostile and ignoring (Shaban, et al., 2012). Thus, current study investigates the sources of stress among nursing students to avoid the damages and further development in the nursing profession.

\section{Research problem}

It is observed that students of private universities face stress. Moreover, nursing students face many issues that hinder the student's capabilities. It is need of the time that researchers should investigate the sources of stress among nursing students so that those factors which create negative influence on the student's academic performance can be avoided.

\section{Significance of study}

The current study investigates the sources of stress among nursing students of private universities of Lahore, Pakistan. The current study will be beneficial for the institutions and hospitals to identify the sources of stress at class room lectures and clinical practices. In addition, the findings of the current study will be helpful for the government and planning authorities to develop the strategy to diminish the sources of stress for the nursing students of private and public universities. Moreover, the results of this study will be useful to the nursing and medical institutes to decrease the key stress elements for the students.

\section{Research objectives}

The objectives of the current study are given in the following:

1) To identify the academic sources of stress among nursing students

2) To identify the clinical sources of stress among the nursing students.

3) To identify the personal sources of stress among the nursing students

4) To identify the environmental sources of stress among the nursing students.

\section{Literature review}

Common stressors for nursing students were identified in the previous studies academic courses, clinical placements, personal and environmental issues. Academic stressors like over burden of work, exam, the fear of failure and concerns associated with academic staff have been recognized (Pulido, et al., 2012). Negative perception towards nursing profession, disrespectful attitude of physicians towards nurses and humiliating behavior of staff are collective sources of stress among the nursing students (Cohen, 1981). Likewise, work load of assignments and clinical rotation become the reason of nursing student's low academic performance (Zhao, et al., 2015).

Nursing student's clinical placement also produces stress where students experience destruction from the standardized practices, indifference from more experienced nurses, hostile environment in hospital wards and criticism from staff and patients (Pulido, et al., 2012).

Additionally, students also face stress due to some personal sources or characteristics like low confidence and it has significant relationship with student's academic performance (Kim, et al., 2010).“The study emphasizes that academic factors contribute the highest level of stress among the Saudi nursing students, followed by environmental factors while interpersonal factors has the lowest influence (Abeer Saad Eswi, 2013). Likewise, the study reveals that 
most significant stressor among African nursing students in USA is academics sources, financial sources and interpersonal sources (Pryjmachuk, et al., 2007). The financial status of the students was one of the most associated factors related to stress among university students (Redhwan, et al., 2009). Lim, (2008) emphasizes that student's health is also important to be considered as the personal source of stress.

In view of the potential long term benefits of managing stress in a more effective way, it is important for students to develop such skills early in their medical career (Lim et al., 2008). Therefore, the current study aimed to explore the sources of stress among nursing students of University level, so that they can identify the stressors and may develop the strategy to cope them.

\section{Methodology}

The cross sectional study design is selected because the study is conducted on the limited scale and in limited time duration. The target population of the current study was the nursing students of private institutes. The convenient sampling technique was used and the nursing students of The University of Lahore were selected for data collection. Participant's confidentiality and privacy was assured and the letter of permission was obtained from the head of department of Lahore school of Nursing, to proceed the research. Time line for this study was from January,2016 to May, 2016. Total population of the nursing students at Lahore school of Nursing department was175 and Slovin's formula applied to calculate the sample size on the basis of available population. Thus, the sample size of the current study was 122 nursing students. The study includes the students who were enrolled for Post RN BS Nursing, 2 years and BSNursing4-year degree program in nursing department of The University of Lahore, Pakistan.

Self-administered questionnaire technique was used to distribute the questionnaire to the nursing students. The questionnaire of stressors among nursing students (Academic sources, clinical sources, personal and environmental sources) of Zhao (2015) which was based on 5point Liker scale was used to collect the data. The questionnaire was distributed to the participants through the faculty in the class room and 15 minutes were given to fill the questionnaire. SPSS 21 version was used to analyze the data and descriptive analysis test was performed to test the frequencies, percentages and graphical representation. Cronbach alpha has described to test the reliability of the instrument. Similarly, KMO and Bartlett's test was applied to test the validity of the instrument

\section{Results and analysis}

Descriptive analysis of the current study is given in the following

\section{Demographics}

\section{Gender}

Nursing students of the University of Lahore participated in the current study. Total 122 nursing students participated in this study. The distribution of demographics is given in the table 1. It shows the respondent's gender distribution. The results show that females were in majority in the respondents as $60.7 \%$ whereas, $39.3 \%$ males participated in current study.

Table 1. Gender

\begin{tabular}{|ll|l|l|l|l|}
\hline & Frequency & Percent & Valid Percent & $\begin{array}{l}\text { Cumulative } \\
\text { Percent }\end{array}$ \\
\hline \multirow{4}{*}{ Valid } & Male & 48 & 39.3 & 39.3 & 39.3 \\
& Female & 74 & 60.7 & 60.7 & 100.0 \\
& Total & 122 & 100.0 & 100.0 & \\
\hline
\end{tabular}


Table 2. Age

\begin{tabular}{|l|l|l|l|l|}
\hline & Frequency & Percent & $\begin{array}{l}\text { Valid } \\
\text { Percent }\end{array}$ & $\begin{array}{l}\text { Cumulative } \\
\text { Percent }\end{array}$ \\
\hline Below 20years & 6 & 4.9 & 4.9 & 4.9 \\
20 - 25years & 60 & 49.2 & 49.2 & 54.1 \\
Valid $26-$ 30years & 48 & 39.3 & 39.3 & 93.4 \\
Above30years & 8 & 6.6 & 6.6 & 100.0 \\
Total & 122 & 100.0 & 100.0 & \\
\hline
\end{tabular}

The distribution of nursing student's age is between 18 to 50 years is given in table 2. The results show the distribution of the age of respondents as $49.2 \%$ from age group of $20-25$, $39.3 \%$ were from age group of $26-30,4.9 \%$ were from below 20 years and $6.6 \%$ belongs to the age of above 30 years.

Table 3. Professional Qualification

\begin{tabular}{|ll|l|l|l|l|}
\hline & Frequency & Percent & $\begin{array}{l}\text { Valid } \\
\text { Percent }\end{array}$ & $\begin{array}{l}\text { Cumulative } \\
\text { Percent }\end{array}$ \\
\hline \multirow{5}{*}{ Valid } & Diploma in General Nursing & 9 & 7.4 & 7.4 & 7.4 \\
& Diploma in Midwifery & 1 & .8 & .8 & 8.2 \\
Both General Nursing and & 72 & 59.0 & 59.0 & 67.2 \\
& Midwifery & 40 & 32.8 & 32.8 & 100.0 \\
No Professional Education & 122 & 100.0 & 100.0 & \\
Total & &
\end{tabular}

The distribution of nursing student's qualification is given in table 3. The results show that the $59 \%$ of the students have qualified both Diploma in General Nursing \& Midwifery. However, $32.8 \%$ of the respondents had no professional qualification.

Table 4. Professional experience

\begin{tabular}{|ll|l|l|l|l|}
\hline & Frequency & Percent & Valid Percent & $\begin{array}{l}\text { Cumulative } \\
\text { Percent }\end{array}$ \\
\hline \multirow{4}{*}{ Valid } & No Experience & 40 & 32.8 & 32.8 & 32.8 \\
& $2-8$ Years & 76 & 62.3 & 62.3 & 95.0 \\
& $9-14$ Years & 3 & 2.5 & 2.5 & 97.5 \\
& 15 - 20 Years & 3 & 2.5 & 2.5 & 100.0 \\
& Total & 122 & 100.0 & 100.0 & \\
\hline
\end{tabular}

The distribution of nursing student's experience is given in table 4 . The results show that $63.2 \%$ of the respondents have experience of $2-8$ years whereas $32.8 \%$ of the respondents have no experience

\section{Reliability and validity}

To observe the reliability of the instrument of the current study, Cronbach Aplha test is used and the Cronbach Alpha value of the current study instrument is 0.877 that shows the reliability of the instrument. Moreover, the validity of the instrument is also tested through $\mathrm{KMO}$ and Bartlett's test as the results show that KMO value is $0.747(>0.50)$ and Bartlett's test is significant $(\mathrm{P}<0.05)$, which show that instrument is valid. 
Table 5. Validity of Instrument

\begin{tabular}{|c|c|c|}
\hline \multicolumn{2}{|l|}{ KMO and Bartlett's Test } & \\
\hline $\begin{array}{l}\text { Kaiser-Meyer-Olkin Measure of Sampling Adequacy. } \\
\text { Bartlett's Test of Sphericity }\end{array}$ & $\begin{array}{l}\text { Approx. Chi-Square } \\
\text { Df } \\
\text { Sig. }\end{array}$ & $\begin{array}{l}.747 \\
1087.247 \\
190 \\
.000\end{array}$ \\
\hline
\end{tabular}

\section{Academic sources as stressor}

This study analyzes the descriptive statistics of the responses of the nursing students. The study undergoes four main categories of stressors which are academic, clinical, personal and environmental. The sample responses of sources of stress among nursing students are described under four main categories in form of tables. Table 6 shows the responses of the nursing students regarding academic sources of stress. The results prove that $61.5 \%, 48.4 \%$, $47.5 \%, 47.5 \%, 39 \%$ and $49.2 \%$ of the respondents were strongly agree on the questions from 1 to 6 respectively, regarding the academic sources as stressors for the nursing student of private universities. This explains that nursing students are prone to stress through the academic sources of stress.

Table 6. Frequency Distribution (Academic sources of stress)

\begin{tabular}{|l|l|l|l|l|l|l|l|}
\hline S. No & Academic Sources of Stress & SD & DA & N & A & SA & Total \\
\hline $\mathbf{1}$ & $\begin{array}{l}\text { Frequent graded activities are } \\
\text { very stressful. }\end{array}$ & $3.3 \%$ & $3.3 \%$ & $3.3 \%$ & $28.7 \%$ & $61.5 \%$ & $100 \%$ \\
\hline $\mathbf{2}$ & $\begin{array}{l}\text { Stress level increases due to } \\
\text { getting lower grades then } \\
\text { anticipation. }\end{array}$ & $8 \%$ & $2.5 \%$ & $1.6 \%$ & $46.7 \%$ & $48.4 \%$ & $100 \%$ \\
\hline $\mathbf{3}$ & $\begin{array}{l}\text { Challenging courses and } \\
\text { missing too many classes } \\
\text { contribute to stress. }\end{array}$ & $0 \%$ & $6.6 \%$ & $12.3 \%$ & $33.6 \%$ & $47.5 \%$ & $100 \%$ \\
\hline $\mathbf{4}$ & $\begin{array}{l}\text { Inability to balance study and } \\
\text { leisure time is source of stress. }\end{array}$ & $0 \%$ & $6.6 \%$ & $12.3 \%$ & $33.6 \%$ & $47.5 \%$ & $100 \%$ \\
\hline $\mathbf{5}$ & $\begin{array}{l}\text { Inconsiderate and insensitive } \\
\text { instructors also cause stress. }\end{array}$ & $1.6 \%$ & $2.5 \%$ & $13.1 \%$ & $43.4 \%$ & $39.0 \%$ & $100 \%$ \\
\hline $\mathbf{6}$ & $\begin{array}{l}\text { Lack of expected career } \\
\text { advancement, promotion and } \\
\text { fear of future create stress. }\end{array}$ & $.8 \%$ & $5.7 \%$ & $7.4 \%$ & $36 . .9 \%$ & $49.2 \%$ & $100 \%$ \\
\hline
\end{tabular}

(SD = Strongly Disagree, DA = Disagree, $\mathbf{N}$ = Neutral, A = Agree, SA = Strongly Agree)

\section{Clinical sources as stressor}

Table 7 depicts the frequency distribution of clinical sources of stress. The results show that $44.3 \%, 31.1 \%, 23.8 \%, 34.4 \%, 29.5 \%$ were strongly agree on the questions from 1 to 6 respectively, regarding the clinical sources as stressors. This explains that nursing students are prone to stress through the clinical sources of stress.

Table 7. Frequency distribution (clinical sources of stress)

\begin{tabular}{|l|l|l|l|l|l|l|l|}
\hline S. No & Clinical Sources of Stress & SD & DA & N & A & SA & Total \\
\hline $\mathbf{1}$ & $\begin{array}{l}\text { Maintaining a balance } \\
\text { between clinical work and } \\
\text { studying increases stress. }\end{array}$ & $0 \%$ & $8.2 \%$ & $7.4 \%$ & $40.2 \%$ & $44.3 \%$ & $100 \%$ \\
\hline $\mathbf{2}$ & New clinical situations, & $.8 \%$ & $16.4 \%$ & $13.9 \%$ & $37.4 \%$ & $31.1 \%$ & $100 \%$ \\
\hline
\end{tabular}


South American Journal of Nursing

Volume 2, Issue 1, 2016

\begin{tabular}{|l|l|l|l|l|l|l|l|}
\hline & $\begin{array}{l}\text { unfamiliar patient's diagnosis } \\
\text { and treatment promote stress } \\
\text { level. }\end{array}$ & & & & & & \\
\hline $\mathbf{3}$ & $\begin{array}{l}\text { Differences between the ideal } \\
\text { practices learned in school and } \\
\text { real situations in the } \\
\text { healthcare environment cause } \\
\text { of stress. }\end{array}$ & $0 \%$ & $7 \%$ & $18.0 \%$ & $25.5 \%$ & $23.8 \%$ & $100 \%$ \\
\hline $\mathbf{4}$ & $\begin{array}{l}\text { Humiliating behavior of } \\
\text { physicians and being criticized } \\
\text { in front of patients is reason of } \\
\text { stress. }\end{array}$ & $.8 \%$ & $12.3 \%$ & $12.3 \%$ & $40.2 \%$ & $34.4 \%$ & $100 \%$ \\
\hline $\mathbf{5}$ & $\begin{array}{l}\text { Unfriendliness from more } \\
\text { senior staff and fear of making } \\
\text { mistakes in patient care is a } \\
\text { cause of stress in clinical } \\
\text { setting. }\end{array}$ & $1.6 \%$ & $12.3 \%$ & $10.7 \%$ & $45.9 \%$ & $29.5 \%$ & $100 \%$ \\
\hline
\end{tabular}

(SD = Strongly Disagree, DA = Disagree, $\mathbf{N}$ = Neutral, A = Agree, SA = Strongly Agree)

\section{Personal sources as stressors}

Table 8 explains the frequency distribution of personal sources of stress. The results show that $39.3 \%, 45.9 \%, 42.6 \%, 44.9 \%$ of the students were agree on the questions from 1 to 6 respectively, regarding the personal sources as stressors for nursing students of stress. This explains that nursing students face stress through the personal sources of stress.

Table 8. Frequency distribution (Personal sources of stress)

\begin{tabular}{|l|l|l|l|l|l|l|l|}
\hline S. No & $\begin{array}{l}\text { Personal Sources as } \\
\text { Stressors }\end{array}$ & SD & DA & N & A & SA & Total \\
\hline $\mathbf{1}$ & $\begin{array}{l}\text { Changes in sleeping } \\
\text { pattern/lack of sleep enhance } \\
\text { stress. }\end{array}$ & $0 \%$ & $15.6 \%$ & $8.2 \%$ & $39.3 \%$ & $36.9 \%$ & $100 \%$ \\
\hline $\mathbf{2}$ & $\begin{array}{l}\text { Financial problems are main } \\
\text { source of stress. }\end{array}$ & $1.6 \%$ & $11.5 \%$ & $8.2 \%$ & $45 . .9 \%$ & $32.8 \%$ & $100 \%$ \\
\hline $\mathbf{3}$ & $\begin{array}{l}\text { Decline in personal health } \\
\text { contribute a lot to stress. }\end{array}$ & $1.6 \%$ & $13.1 \%$ & $10.7 \%$ & $42.6 \%$ & $32.0 \%$ & $100 \%$ \\
\hline $\mathbf{4}$ & $\begin{array}{l}\text { Lack of confidence and } \\
\text { inability to decision making } \\
\text { enhance stress. }\end{array}$ & $0 \%$ & $13.9 \%$ & $10.7 \%$ & $44.9 \%$ & $31.1 \%$ & $100 \%$ \\
\hline
\end{tabular}

(SD = Strongly Disagree, DA = Disagree, $\mathbf{N}=$ Neutral, A = Agree, SA = Strongly Agree)

\section{Environmental sources as stressor}

Environmental factors also create stress among the nursing students. Table 9 shows that most of the students responded between neutral to strongly agree regarding the environmental factors as stressor for the nursing students. Thus, it proves that environmental factors also create stress for the nursing students.

Table 9. Frequency Stressors (Environmental sources of stress)

\begin{tabular}{|l|l|l|l|l|l|l|l|}
\hline $\begin{array}{l}\text { S. } \\
\text { No }\end{array}$ & $\begin{array}{l}\text { Environmental Sources as } \\
\text { Stressors }\end{array}$ & SD & DA & N & A & SA & Total \\
\hline $\mathbf{1}$ & $\begin{array}{l}\text { Lack of recreational } \\
\text { facilities/activities during } \\
\text { semester is a source of stress. }\end{array}$ & $1.6 \%$ & $17.2 \%$ & $14.8 \%$ & $33.6 \%$ & $32.8 \%$ & $100 \%$ \\
\hline
\end{tabular}




\begin{tabular}{|l|l|l|l|l|l|l|l|}
\hline $\mathbf{2}$ & $\begin{array}{l}\text { Difficulties with transportation } \\
\text { also a source of stress. }\end{array}$ & $0 \%$ & $11.5 \%$ & $16.4 \%$ & $35.2 \%$ & $36.9 \%$ & $100 \%$ \\
\hline $\mathbf{3}$ & $\begin{array}{l}\text { Not enough leisure time } \\
\text { creates frustration. }\end{array}$ & $0 \%$ & $8.2 \%$ & $18.0 \%$ & $39 . \% 3$ & $34.4 \%$ & $100 \%$ \\
\hline $\mathbf{4}$ & $\begin{array}{l}\text { Absence of calm and quite } \\
\text { environment in class increases } \\
\text { stress level. }\end{array}$ & $0 \%$ & $13.9 \%$ & $12.3 \%$ & $45.1 \%$ & $28.7 \%$ & $100 \%$ \\
\hline $\mathbf{5}$ & $\begin{array}{l}\text { Congested class room creates } \\
\text { anxiety. }\end{array}$ & $4.9 \%$ & $15.6 \%$ & $13.1 \%$ & $35.1 \%$ & $31.1 \%$ & $100 \%$ \\
\hline
\end{tabular}

(SD = Strongly Disagree, DA = Disagree, $\mathbf{N}=$ Neutral, A = Agree, SA = Strongly Agree)

\section{Discussion}

In the current study four main categories of stressors were selected which are academic, clinical, personal and environmental. Table 6 show the response of the nursing students was highest to the strongly agree regarding the academic stressor questions. Thus, results show that students face highest level of stress from the academic sources. Similarly, nursing students face the stress through the clinical rotation. The situations in clinical practice that produces the stress due to the differences between the ideal practice learned in the classes and real situations in the healthcare environment, indifference from more senior staff, being criticized in front of staff and patients (Pulido, et al.,2012). Thus, results (Table 7) of the current study also show that nursing students face stress through the clinical practices.

In addition, table 8show that students were majorly agrees that personal factors also create stress among the nursing students. The students feel lack of self-confidence in general. Confidence is crucial for being able and sufficient in one's profession (Kim, et al., 2010). Likewise, financial status of the students is one of the most associated factors related to stress, might be financial crisis affected the entire world and the rise in cost of living. The study finds that lack of financial support is one of the factors that contributed to stress among university students (Redhwan, 2009).

Furthermore, environmental factors also cause stress among nursing students. Table 9 clearly shows that the nursing students were agreed regarding environmental factors as the stressor for the nursing students.

Table 10. Descriptive Statistics

\begin{tabular}{|l|l|l|l|l|l|l|}
\hline & N & Minimum & Maximum & Sum & Mean & $\begin{array}{l}\text { Std. } \\
\text { Deviation }\end{array}$ \\
\hline Academic Sources & 122 & 2.17 & 5.00 & 522.67 & 4.2842 & .55863 \\
\hline Clinical Sources & 122 & 2.20 & 5.00 & 483.40 & 3.9623 & .65117 \\
\hline Personal Sources & 122 & 1.50 & 5.00 & 481.00 & 3.9426 & .79108 \\
\hline Environmental Sources & 122 & 2.40 & 5.00 & 472.6 & 3.873 & .69909 \\
\hline Valid N (Listwise) & 122 & & & & & \\
\hline
\end{tabular}

Table 10 shows the descriptive statistics of the four stressors which are considered in the current study. The current study considered academic sources, clinical sources, personal sources and environmental sources as the major four contributors to the nursing student's stress. In the table 10, nursing student's response to all the stressors is given. The mean value of the four major stressors shows the major responses of the nursing student to the options of the Likert scale. Moreover, the comparison of the stressors can be seen by the nursing student's response. Thus, nursing student's responded highest factor of stress to the academic sources of stress as the mean value of 4.2842 show that majority of the students were agree and strongly agree on the point that academic sources create stress. Similarly, the nursing students consider clinical sources, personal sources and environmental sources as stressors respectively. However, environmental sources are considered as the lowest source of stress than the other 3 categories. 
South American Journal of Nursing

Volume 2, Issue 1, 2016

\section{Conclusion}

"The current study investigates the major sources of stress among the nursing students of private universities. The sources which are considered as the stressors are academic, clinical, personal and environmental. The study reveals the moderate to high level of stress among the nursing students. The findings of the study indicate that students experience highest level of stress through the academic, however clinical and personal sources as moderate level. Furthermore, environmental stressors as the lowest stressors than the other 3 categories.”

\section{Recommendations}

The current study suggests that high level of academic stress found among the nursing students of private universities, so, it is recommended that authorities should consider this situation in the curriculum. Management should encourage the university faculty and the staff to work in cooperation with the students to improve the use of support services for the students. Further studies should consider the mediations which may provide social and psychosocial support to the nursing students."

\section{Limitations of the study}

This study has also some limitations which can be fulfilled in the further studies. This study conducts research on limited scale due to shortage of time. This is a descriptive study that is done among nursing students of only private universities. The findings of this study are based on the quantitative techniques, so the qualitative approach can also be used to have the better analysis and comparison.

\section{References}

[1.] Cohen-Scali, V. (2003). The influence of family, social, and work socialization on the construction of the professional identity of young adults. Journal of career development, 29(4), 237-249.

[2.] Edwards, D., Burnard, P., Bennett, K., \& Hebden, U. (2010). A longitudinal study of stress and self-esteem in student nurses. Nurse education today, 30(1), 78-84.

[3.] Edward, K. L., Warelow, P., Hemingway, S., Hercelinskyj, G., Welch, A., McAndrew, S., \& Stephenson, J. (2015). Motivations of nursing students regarding their educational preparation for mental health nursing in Australia and the United Kingdom: a survey evaluation. BMC nursing, 14(1), 1.

[4.] Eswi, A. S., Radi, S., \& Youssri, H. (2013). Stress/stressors as perceived by baccalaureate Saudi nursing students. Middle-East Journal of Scientific Research, 14(2), 193-202.

[5.] Findik, U. Y., Ozbas, A., Cavdar, I., Topcu, S. Y., \& Onler, E. (2015). Assessment of nursing students' stress levels and coping strategies in operating room practice. Nurse education in practice, 15(3), 192-195.

[6.] Hayes, B., Douglas, C., \& Bonner, A. (2015). (Article 4) Work Environment, Job Satisfaction, Job Stress and Burnout among Haemodialysis Nurses. Job Satisfaction, Stress and Burnout in Haemodialysis Nurses, 155.

[7.] Kim, M., \& Hwangbo, H. H. (2010). Randomized trial evaluating the aroma inhalation on physiological and subjective anxiety indicators of the nursing students experiencing the first intravenous injection. International Journal of Bio-Science and Bio-Technology, 2(4), 1-9.

[8.] Lim, S., Cortina, L. M., \& Magley, V. J. (2008). Personal and workgroup incivility: impact on work and health outcomes. Journal of Applied Psychology, 93(1), 95.

[9.] Pryjmachuk, S., \& Richards, D. A. (2007). Predicting stress in pre-registration nursing students. British Journal of health psychology, 12(1), 125-144.

[10.] Pulido-Martos, M., Augusto-Landa, J. M., \& Lopez-Zafra, E. (2012). Sources of stress in nursing students: a systematic review of quantitative studies. International Nursing Review, 59(1), 15-25. 
[11.] Redhwan, A. A. N., Sami, A. R., Karim, A., Chan, R., \& Zaleha, M. (2009). Stress and coping strategies among management and science university students: A qualitative study. The International Medical Journal of Malaysia, 8(2).

[12.] Shaban, I. A., Khater, W. A., \& Akhu-Zaheya, L. M. (2012). Undergraduate nursing students' stress sources and coping behaviours during their initial period of clinical training: A Jordanian perspective. Nurse Education in Practice, 12(4), 204-209.

[13.] Zhao, F. F., Lei, X. L., He, W., Gu, Y. H., \& Li, D. W. (2015). The study of perceived stress, coping strategy and self-efficacy of Chinese undergraduate nursing students in clinical practice. International journal of nursing practice, 21(4), 401-409. 